\title{
PENDULAR ROTATORY PATTERN TEST
}

By

JUICH SETOGUCHI

From the Department of Oto-Rhino-Laryngology Facultyof Medicine, Uuiversity of Tokyo (Director: Prof. Ichiro Kirikae)

Pendular rotation test was performed on four different visual conditions, a) the subject was directed to. gaze at a fixed target b) to watch stripes instructed as he was rotated c) to close the eyes, and d) to open the eyes behind an eyepatch.

In the course of $c$ ), the subject was asked to do calculations $\left(\mathbf{c}^{\prime}\right)$.

The amplitude of pendular rotation was approximately $90^{\circ}$.

The period of pendular rotation was $4 \sim 5$ sec. Ocular deviation was recorded electronystagmographically with a time constant of $6 \mathrm{sec}$. The speed of eye deviation was simultaneously registeredwith a time constant of $0.015 \mathrm{sec}$.

As shown in Fig. 1, normal test-subjects showed smooth "sine wave" ocular deviations when rotated while gazing at a fixed target. The eye deviation in a) was largest and decreased in the following order, b), c), $c^{\prime}$ ) and d).

In b), eye deviation was also large. A nystagmus of a large amplitude was always superimposed upon the sine wave.

In c), eye deviation was less than in b), and about the half of that seen in a). The deviation curve showed a sine-wave configuration when no nystagmus was provoked, which was the case for the majority of the observations.

When calculation was imposed $\left(c^{\prime}\right)$, nystagmus was induced.

In d), eye deviation was the smallest of all.

Cases which had peripheral labyrinthine lesions showed generally no different pattern from those of normal recording.

Cases with central lesions showed some particular patterns on pendular rotation test which varied depending on the cases.

In a), some showed nystagmus and saccadic eye tracking. They had a kind of disturbance in oculomotor system.

In b), disturbances were not so clearly shown as by optokinetic pattern (OKP) test, probably because the vestibular input assists the reaction.

In c), some cases with central lesions showed irregularities in deviation curves.

In some cases with central lesions the ocular deviation and total amplitude in $c$ ), $e^{\prime}$ ) and d) were significantly large. These two characteristics in c) and d), that is, the distortion and the large amplitude of ocular deviation were among the important findings to be looked for in central lesions. 


\title{
振子様回転検査の臨床的研究 \\ - Pendular rotatory pattern test (PRP テスト)
}

\author{
による脳幹機能検祖一
}

\section{東京大学医学部耳舉咽喉科学教室（主任：切替一郎教授）}

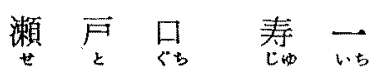

\section{はじめに}

Bárány が回転刺激による眼振反応を，始めて臨床に 灾用して以来, 現在まで眼振を対象とした色々の回転検 查法が和こなわれている．振子様回転刺激は，一方向回 転検查に比較して“なれの現象” (response decline) がないこと，回転中眼振は後眼振と違つて生理的な反 応であること，検查時間が短くてすむことなどの特徴 を有し，さらに電気腿振計 (Electronystagmograph) （ENG）の発達に上り回転梌查の臨訹への応用が試みら れるようになつた。

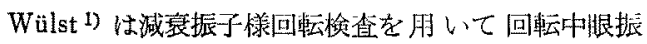
の持繶時間と回転停止後の後眼振の持続時間とを比较す ることで，中枢および末梢前庭障害の鑑別に利用した， Jongkees 2) は振子棣回転中眼振で眼振の方向㗹位性 (DP) が短時間に検査出来ることについて記載し，松 永 ${ }^{\text {》) }}$ は振子椂回転検查を開眼, 閉眼下で抽こない閉眼 による眼振抑制効果を調べた絬果, 末梢性眩最では閉眼 の抑制効果は任とんどなく，中枢性眩霸では抑制効果が みられると述べ, Greiner ${ }^{4)}$ ( (调期 20 秒の振子様回転 刺教で特改的眼振がィニエル病で倠察されるとのべてい， る.

これらの振子様回転㭘查はいづれる腿振の方向墏位 性，持続時間あるいは閉眼による眼振抑制効果を中心之 した検查法である．われわれは振子㺌回転刺激による眼 球運動反射が，異なつた視性条件のもとでどのように装

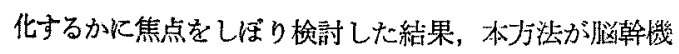
能検查法の一つとして利用しらる可能性について赫告し たい。

\section{I 検查装置}

バラニー回転柃盗用椅子行約 $2 \mathrm{~m}$ の良質のゴムひも の一端を接続し，他側は壁に固定し、ゴムの弾性を利用 して手勘で振子様回転刺激を接こなつた。

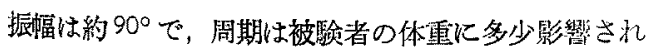
るので 4 秒から 5 秒の正弦波に近い波形をうることがで

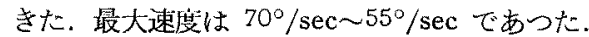

被検者の頭の回転怯可変抵抗器を頭部に装着して記録 した.

ENG による記録は紙の扰くり速度を $0.5 \mathrm{~cm} / \mathrm{sec}$ と した. ENG の時定数は 6 秒，0.015 秒の 2 種としてそ れぞれ眼球の虍位と偏位速度を記録した。

な打検查は淔径 $1.8 \mathrm{~m}$ の視性刺激ドラム内で扣こな われた，ドラム内には巾 $3 \mathrm{~cm}$ の黑色テープが等間隔 に12本䝶りつけて疗る。

\section{II 検查方法}

被检者を回転椅子飞腰掛けさせ，4つの異なった視性 条件のもとで，振子様回転刺激を榆子に加克た，頭部の みの回転は㧍こなわず椅子自体の回忶につれ，頭をから だとともに回転するよら被検者に指示した，

視性条件はｉ）一点注視（a）すなわちドラム内の点 （静止時に被検者の正面にあたる点）を注視する。ii） 開眼正面視 (b)，すなっち開腿正面視で回転刺激中に 眼前を渦ぎるドラム内の黑色テープを見る， iii）閉眼 (c)，iv）遮眼 (d) である.な报閉眼の状態で計算を负 荷させた $\left(\mathrm{c}^{\prime}\right)$.この上らにして記録された振子㥞回転 検查は第 1 図の如くなる。

上段の記録は眼球の偏位を示し，中段は眼球速度を， 下段は頭の回転位置を示す。

眼振は右问きに解発されたときは上向きに，左向きの ばあい下向きになるようにしてある。眼球偏位も同じく

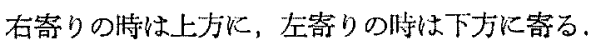

\section{III. 正常人における振子様回転検査の結果}

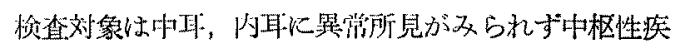
县のない正常侹康者21 例を朋いた，年令分布は16才上 り22オですった。

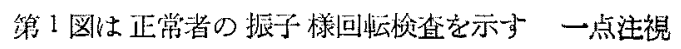
（a）では原波形はなめらかな正弦波を示し，それに伴 つて速度波形はなめらかな余弦波を示した。 
第 1 図正常者の振子椂回忶挨查

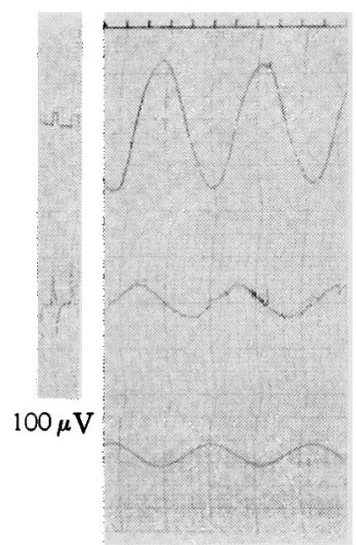

一点注視 (a)

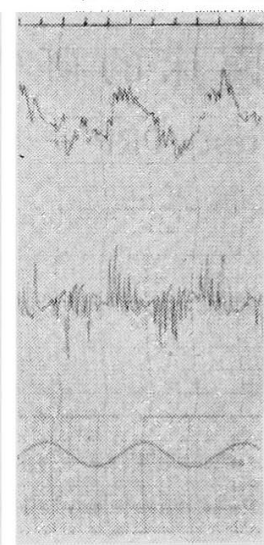

開服让面視（b)

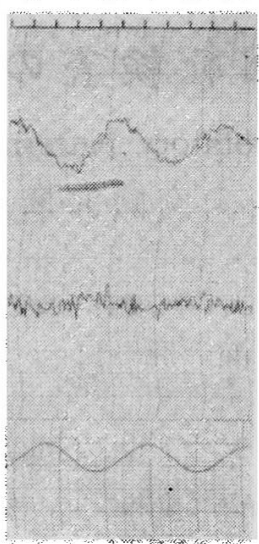

閉 腿 (c)

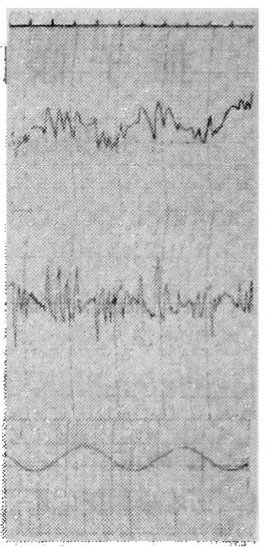

閉限計算 $\left(c^{\prime}\right)$

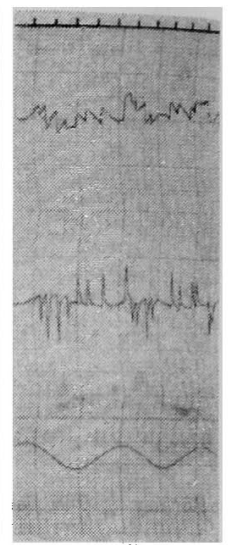

遮 峎 (d)

上段の記録は振子㮏回忶刺激にともなつた煺球偏位を示し，中段の記録は峎球速度を，下段の記録は 頭の位置（振子様回枟刺激）を示す

振子様回枟検査は視性刺激ドラム内で 4 つの異なつた視性条件のもとでおこなわれた，i）一点注視

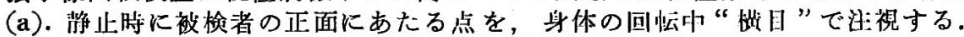

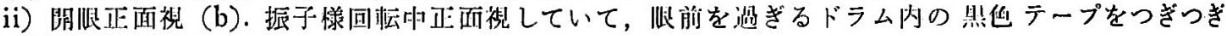
に見る。

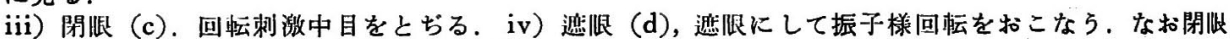
の状態で計算を拈こなつた閉腿喰算 $\left(\mathbf{c}^{\prime}\right)$.

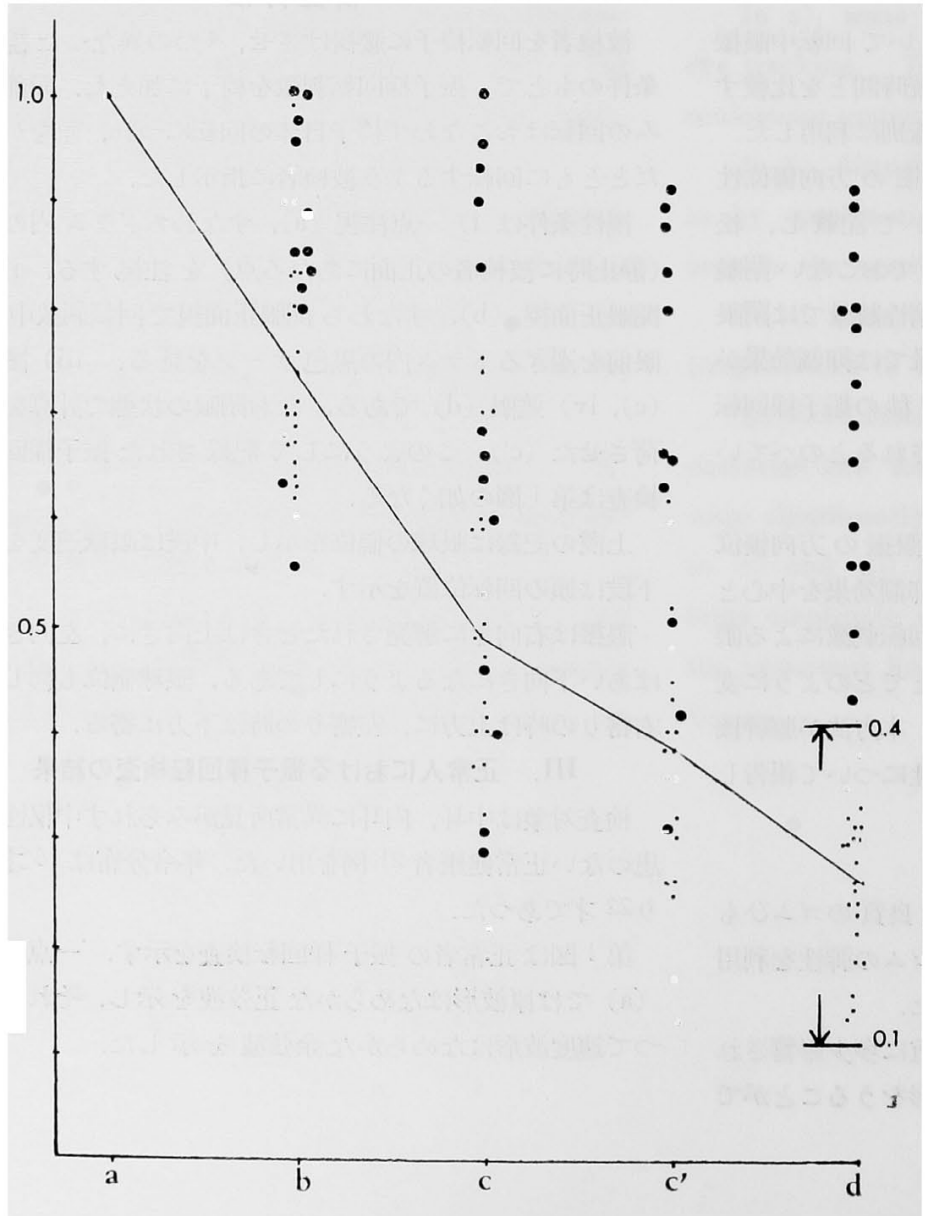

第 2 図振子样回転刺激洔の最大 恨球偏位

一点泆視（a）の最大眼球偏位を 1 と したときの各視性条件 (b) (c), (c'),

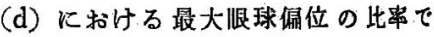
ある。

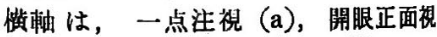
(b)，閉脤 (c)，閉腿計算 $\left(c^{\prime}\right)$ 遮眼 (d) を示す.

小点は正常者の比率で，大きな゙ま る”は中权障害例 (脳幹障害例, 脊能 小腷变性症, 先天性根振など) の比革 である．線は正常者の平均値をあらわ 寸े

中枢障害症例では（c)，(c')，(d) c 顺球偏位の比率が大きく，とくに(d) で藷るしいことが泩目される，また正 常者の（d）ではサンブルが 正规分布 することから正常者 21 例を用いて菜 却限界 $\left(\mathrm{x}_{0}\right)$ を求めると $0.4 \geqq \mathrm{x}_{0} \geqq$ 0.1 なる 
原波形の最大限球偏位は一点注視（a）で最も火きから た. 開腿正面視 (b) では, 原波形の腿球偏位は一点注 視（a）に次いで大きく,そそれに付加された腿振が 観察 された. また眼振数は遮眼 (d) より多く, 眼振緩徐相 の眼球速度む大きかつた。この所見は速度波形で示され ている. 眼振数に左右差はなからた.

開眼 (c)では，眼振の解発は一般的に抑制され，原 波形は正弘波に類似した波形を党がく，眼球偏位は一点 注視 (a) の約半分であつた。 閉眼計算時 $\left(c^{\prime}\right)$ では全 例飞眼振の解発がみられた，遮眼 (d) では, 眼球偏位 はもつとも小さく，一点注視（a）の1/3位であつた.

眼振緩徐相の速度の小さい腿振がみられた。眼振数に 左右差はなからた。

正常健康者 21 例老用いて, 一点注視（a）の眼球偏位 飞対する遮腿 (d) の最大眼球偏位の比率を調べると, 推計学上危険济 $5 \%$ の萧却限界で一点注視 (a) の偏位 1 としたばあい，廘眼 (d) の偏位 $\left(\mathrm{x}_{0}\right)$ は $0.4 \geq \mathrm{x}_{0} \geqq$ 0.1 と补算された(第 2 図).

\section{IV 臨床例における振子様回転検査の結果}

\section{i) 末梢迷路性疾患}

一般似正常例との差は注とんどみられなからた，但 ᄂ.自発眼振の存在する痛例では眼振数江左右差が観察さ れたまた特殊なばあいとして，たと党ば両側迷路廃絶 例 (第 3 図)では当然ながら閉眼 (c) 廘眼 (d) 時に 眼球偏位が全くなく、眼振も観察されなかつた。

ii) 中枢吽疾腎

症例は聴神経腫瘍，脳幹障害控例，脊䯣小脳变性症，

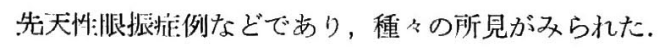

一点注視（a）では，一般的に原波形，微分波形共飞 なめらかな正弦波を党がかないが粗大な眼振が観察され たり（第6 図)、(第7 図)，(第9図)，左右方向の眼振 が観察された（第6図），(符9図)。一点注視（a）の原 波形で，ゆるやかな眼運動に混って同方向にむかう急速 な腿運動 (saccadic eye tracking) の観察される症例 があり (第 5 図)，このような惊例では時に 原波形で眼 振との区別が出来にくいこともあるが，速度波形では波 形の頂点に“ヒゲ”の生えた特徽的な形を示した。

開腿正面視（b) では，限振の解発が悪く，眼球運動 は不規則であった。

この上らな症例では OKP テスト ら) で眼振の解発が わるからた。

OKP テストで眼振の解発が非常に茝い例（第6 図) では, 關眼正視 (b) の眼球運䡃は遮眼 (d) での眼球 浬動飞極めて上く頑似した。

閉腿（c）では，腿球偏位が大きく，眼振の緩徐相の 速度が大きかつた：また正常例に比して非対称性の眼球 運動がめだつた。

閉腿計算（c）では腿球偏位が大きく 眼振の緩徐相 の速度が大きからた．また正常に比して，なめらかな正 弦波をえがかず，波形の非対称性もめだつた。

廘眼 (d) では, 眼球偏位が大きく，眼振の緩徐相の 速度が大きからた。 また腿球偏位が一点注視（a）の半

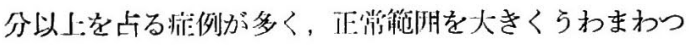
ていた.

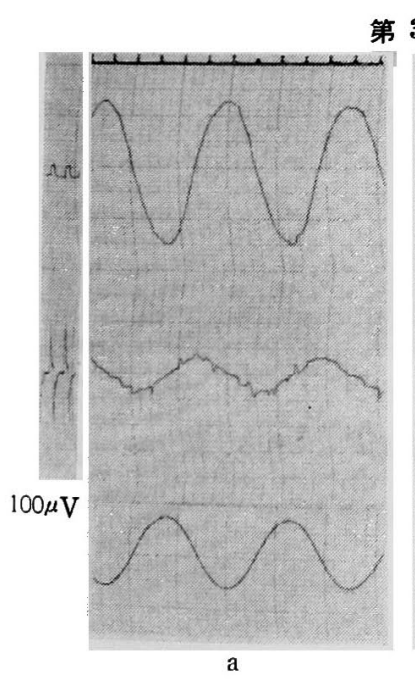

$10-37$
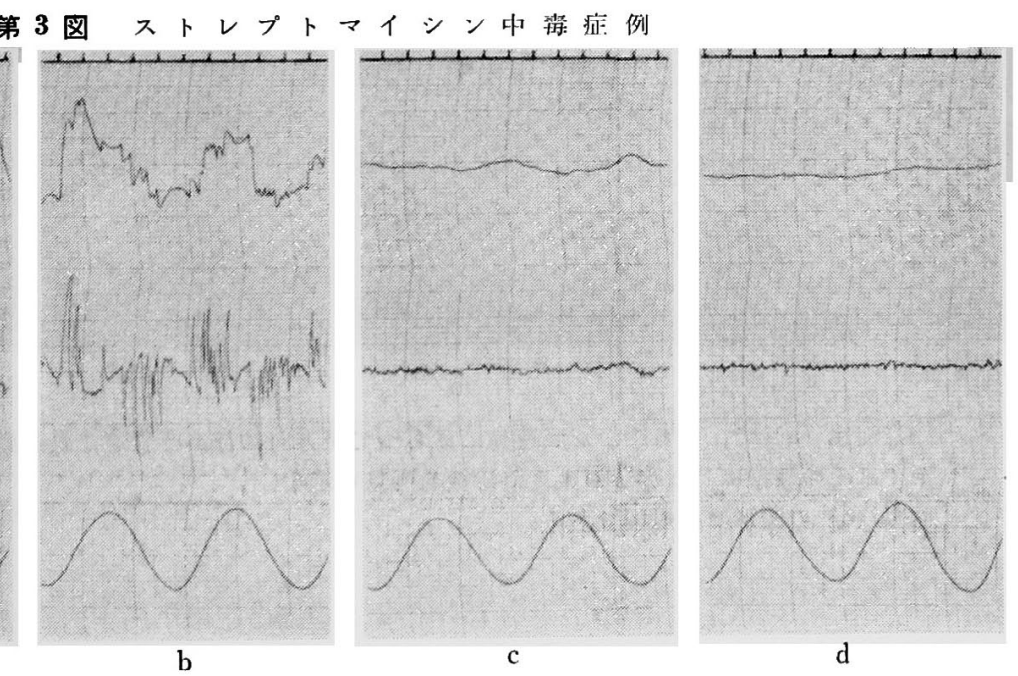

閉限 (c), 遮腿 (d) で恨運動がほとんどみられない 
第 4 図 腷 幹障害症 例

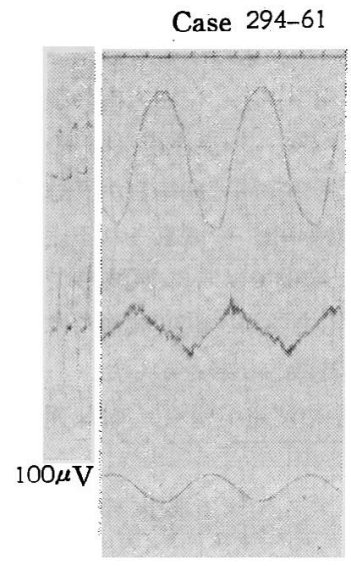

a

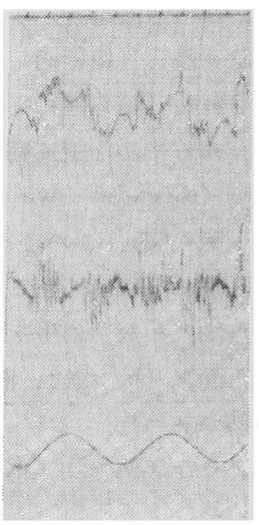

b

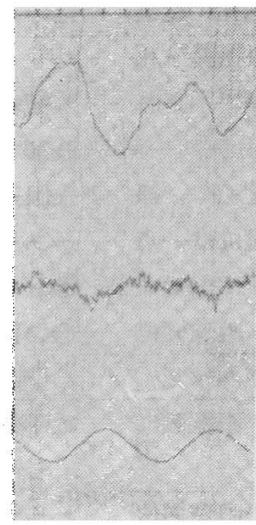

c

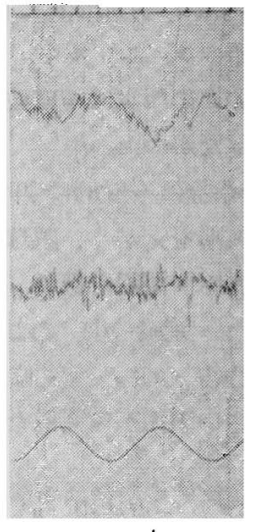

$c^{\prime}$

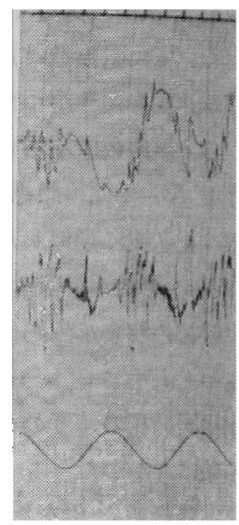

d

一点注視（a）で微分波形はもちろん原波形共になめらかな正㢱波を光がかない，閉服（c）で波形 は非対称的で不規則である。遮腿（d）で最大腿球偏位は大きく（a）の半分以上を占る。また眼振 緅徐相の速度も大きい。

第 5 図脳幹障害症例

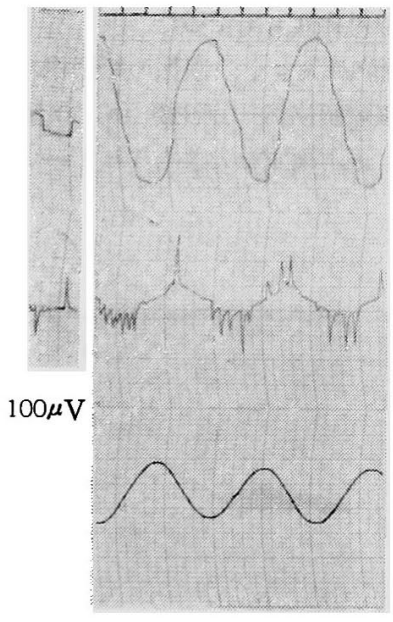

a

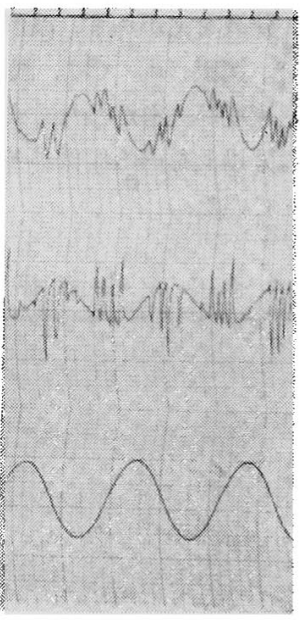

b

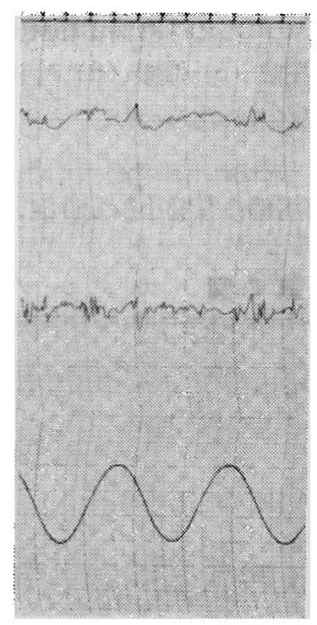

c

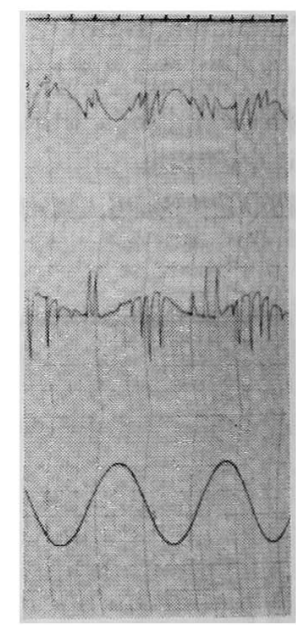

d

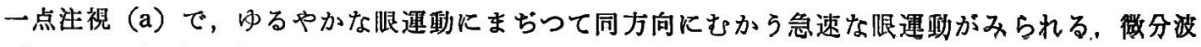
形ではその極位に“ヒゲ”の生兊た特徽的所見を示す，

閉眼（c）の波形は不規則である。 


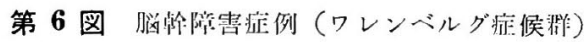

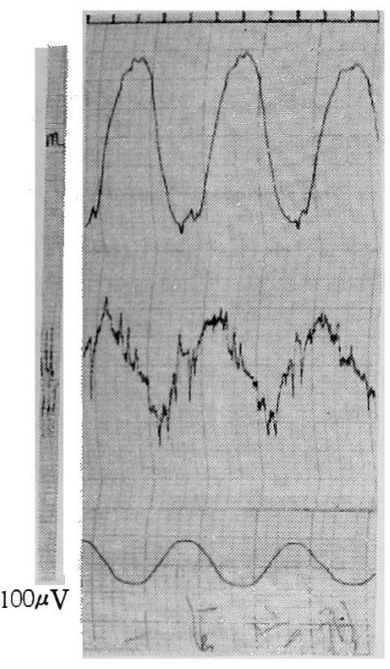

a

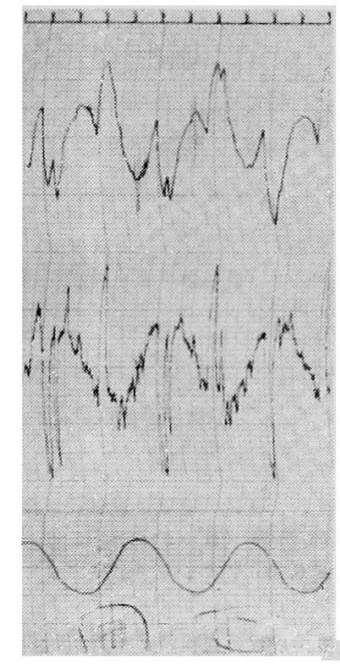

b

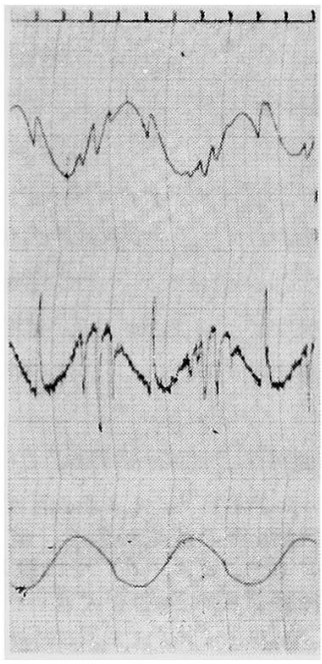

c

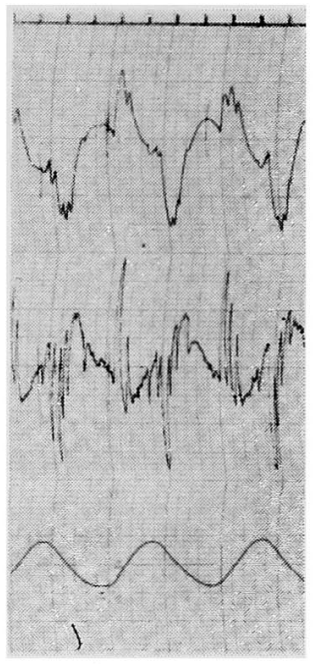

d

一点注視（a）では粗大な煺振が観察される。また波形そのものも正然波を党がかない，

閒限正面視（b）では腿振の解発がわるい。閒限正面祝（b）の波形と遮限（d）の波形は注とえど 同じ形を示す

遮腿（d）では最大腿球偏位が大きく（a）の半分以上を占る，腿振緩徐相の速度も大きい

第 7 図春䠗小慆变性症

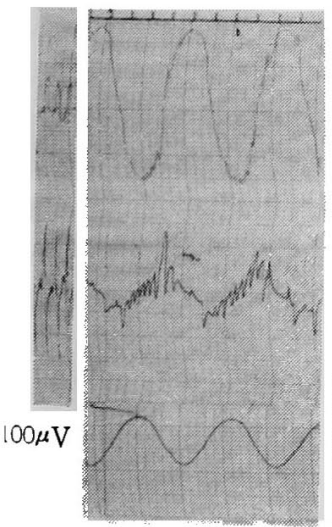

a

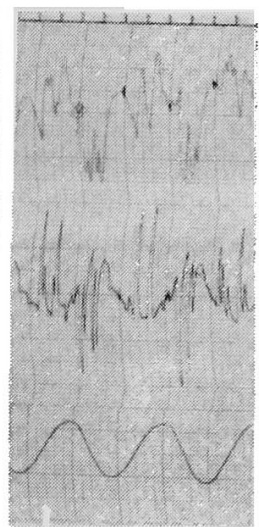

b

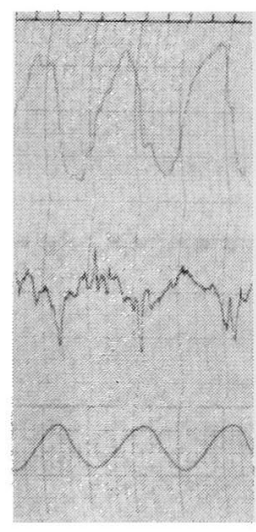

c

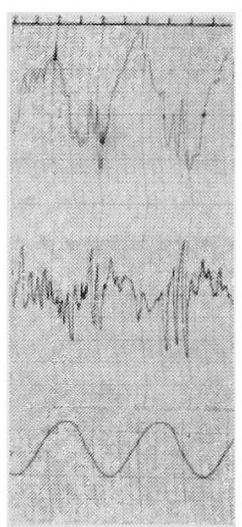

$c^{\prime}$

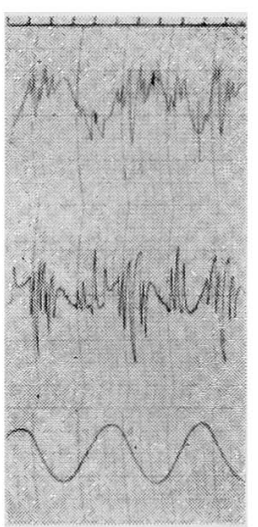

$\mathrm{d}$

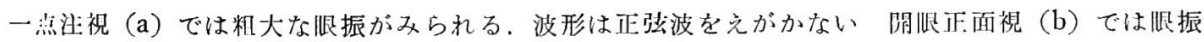

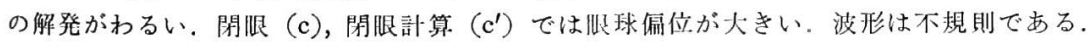

遮顺（d）で，榴振緩徐相の速度が大きい。 


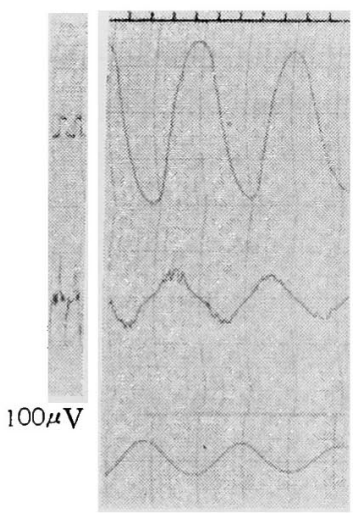

a

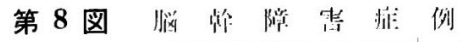

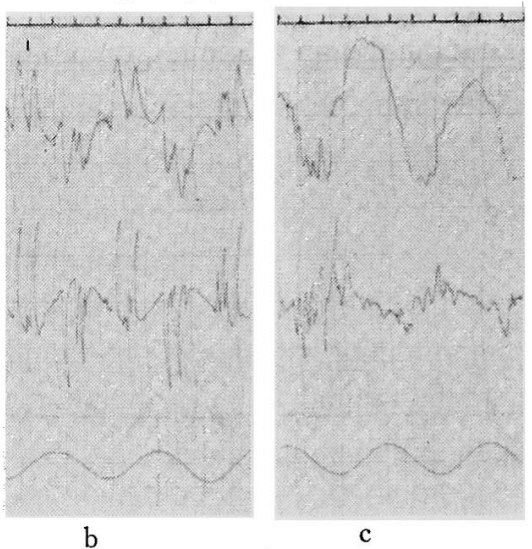

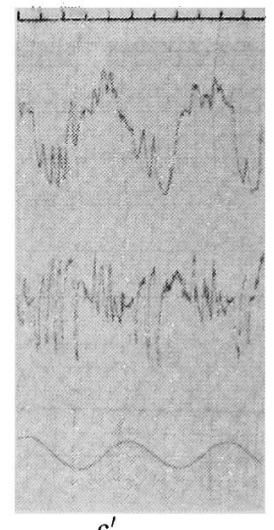

$\mathrm{c}^{\prime}$

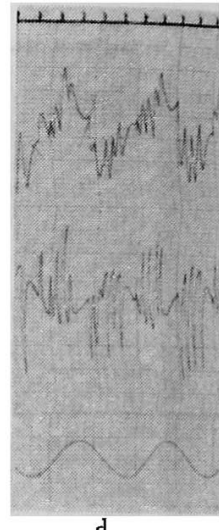

d

開腿正面視（b）では眼振の解発が悪く，波形は遮限（d）の波形に似ている.

閉腿 $(c)$, 閉腿計算 $\left(c^{\prime}\right)$, 遮腿 (d) では眼球偏位が大きい 遮腿 (d) での腿球偏位は (a)の半 分以上を占る。腿振綬徐相の速度も大きい。

第 9 図（先天性眼振例）

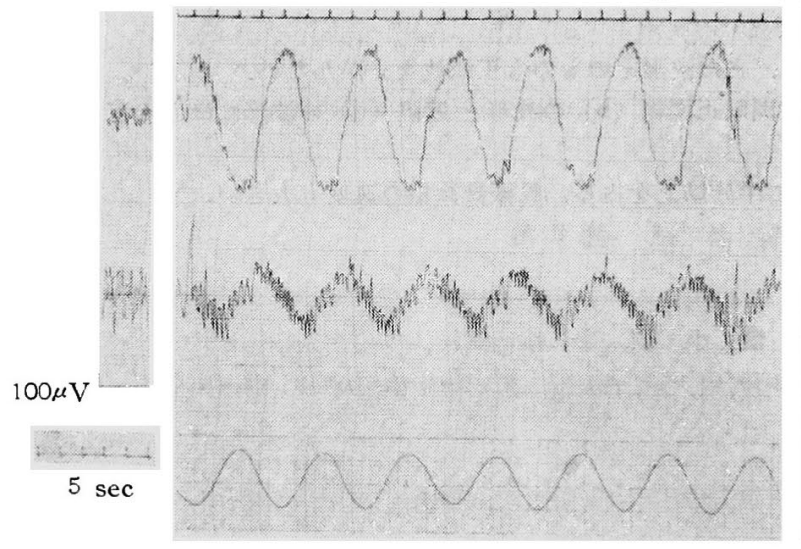

a

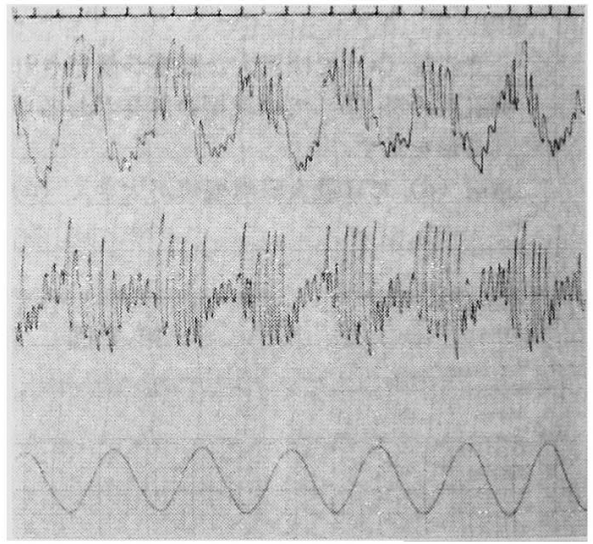

b
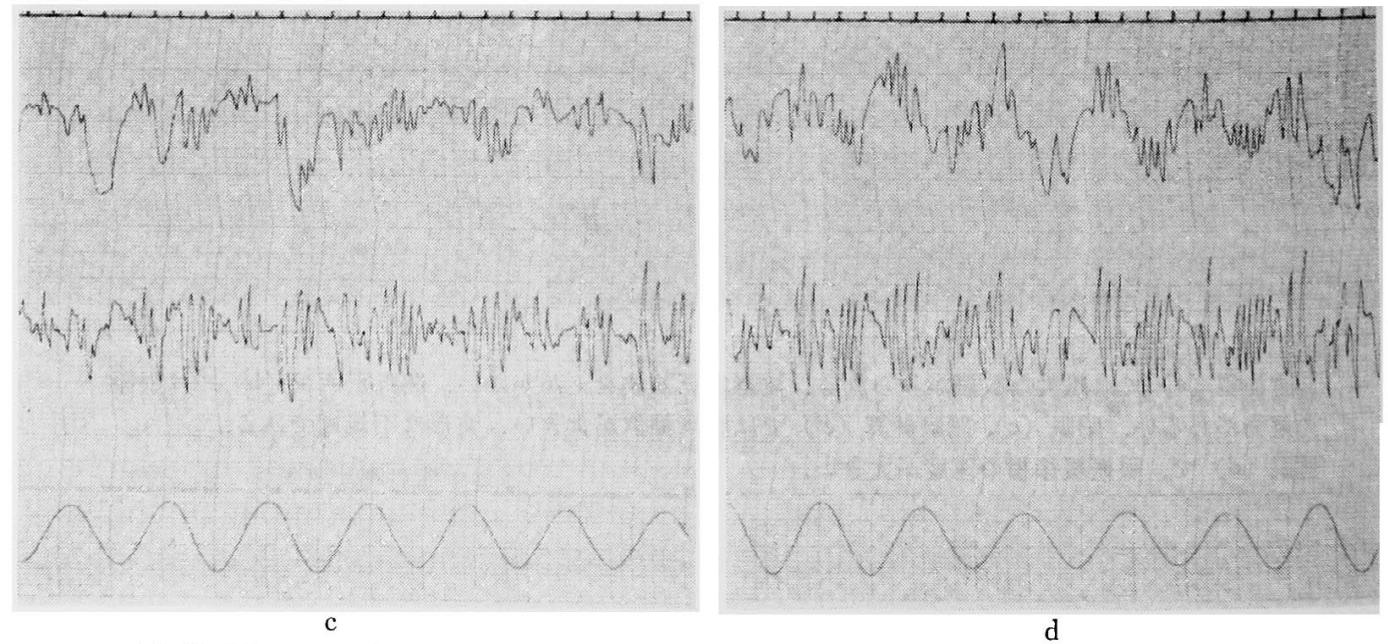

一点注視（a）では腿球速動は憸めて不規則で波形全体に限振が観察される，開腿正面視 (b) で は左右での限振の大きさが異つている。閉眼（c）では腿球偏位が大きく波形は不規則である。 遮腿（d）では限球偏位が大きく（a）の半分以上を占る，根振綬徐相の速度も大きい。 
(1) まず挨榃方法についてのべる。

われわれは一点注視 (a), 開腿正面視 (b)，閉眼 (c) 遮眼（d）の4つの視性条件で振子様回転榆查を抗こな つた。これらの視性条件は奏地蹈床の自発眼振観察で基 本的に使用されている視性条件であり，それでれル重要 な意味をる。

固視能力和よび視性璭動性眼反射は腿運動系(Oculomotor system) の重要な機能である

(a)では振子様回廂刺激下に固視能力の検奋、をおこな い，(b)では振子様刺激下に視性連動性腿振检查を和こ なっている.

これに反し，閉眼，遮眼では視器系の刺激は全くな く，振子様刺激による迷路眼反射を純粋に見ていること になる.

しかし湢㦿的に閉眼時, 遮眼時の眼球運動は異なる埸 命が多〉，閉腿時眼振がみられない例でも浐腿㭙眼振が 活発に现現する。这儿閉眼時眼振が活発化されることも 稀にあるが，一般的には閉腿時には腿振は抑制されるこ とが多い。

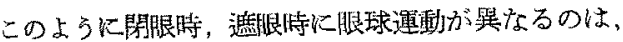

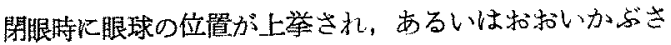
つた眼瞼が運動を抑制するとも考光られるが，しばしば 開眼時計算に上り活発な自発眼振のみられることから考 えると，むしろ脳幹の活動性の差が重要な要因ではない かと推定される。

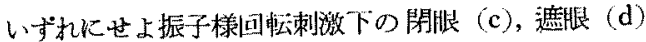
では視器系の刺激は全く除外され，外からの刺激は前庭 迷路とくに外半規管を通じてのみ脳幹に入る。

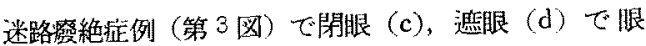

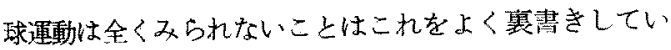
る。

またわれわれは振子様回転刺激の 周期を4〜5 秒で和 こなつたが，この周期は日常生活で覑繁にみられる比較 的生理的な周期に近く，また理論似にタプラが応じやす

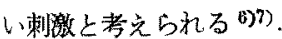

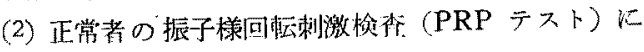
W.

正常者（第1図）では，固視能力が良贬なため一点注視

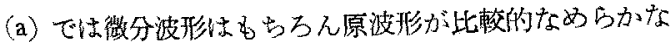
正弦波をえがき，眼振がこれに重なることはない，開服 正面視（b）では活発な眼振の解発がみられる。

閉眼（c）では多少眼振の混ずることもあるが，振子

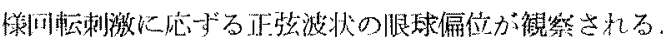

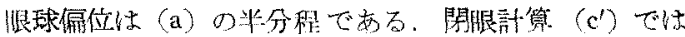
眼振が雨なる。

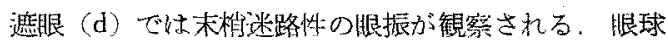

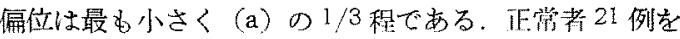
用いて (a) の最大眼球偏位に刘 寸る 遥眼 (d) の眼球

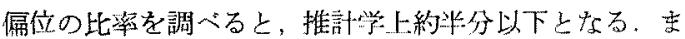
た眼振緮徐相の速度はゆるやかである。

閉眼 (c), 遮眼 (d) での眼球運動は大支詨称的で規 則的であり，次にのべる中枢障畫例とは落るしく黑なつ てい五。

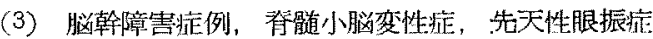
例などにみられる（PRTテスト）所見について。

i)一点注視（a）では，微分波形はもちろん原波形 共になめらかな正弘波を克がかないことが多い。

とくに粗大な眼振が観察されるばあいや，ゆるやか

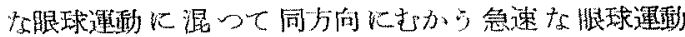
(saccadic eye tracking) が観祭されるばあい，眼连動 系 (oculomotor system) の障䨋を推定出来る，

粗大な腿振は（第6图，第7 图，第9图）で覞繁され

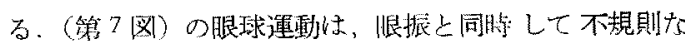
眼酎動が鼬つている。

（第5图）では内るやかな腿球連動に混つて同方间に むから急速な腿運動がみられ微分波形ではその梅位に "ヒゲ"の牛光た特徽的な形を示している。

ト記のごとき現象は次の占に解橎比来ないだろら 小。

われわれ《物休を国視す名際，朖朌の共同運動，措抗

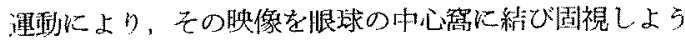

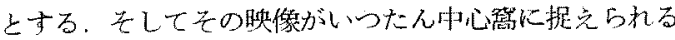

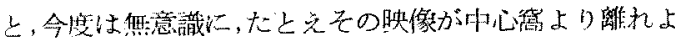
うとしてを，その方向に眼球を動かす眼筋のト一ス スが

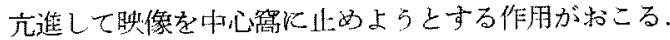

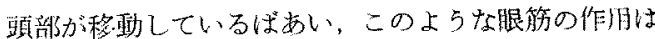
瞬閒僢閂におこなわれる必要があり，したがつてこれら

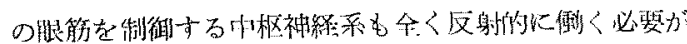
b石

このよらなフイードバックが障琴されると、䀧舫の相

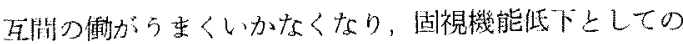
耀大な眼振や， saccadic eye tracking が微察されるの である5。(第5国)では固視線が安定せず阅視点を 漓れて遅れがちとなり，それを矯正するよう，急速な 组球運動が叔こるため，此較的のるやかな眼球運動の中 
に同方向にさから急速な眼球媈動 (saccadic eye tracking) が暀じている。

ii) 開腿正面視 (b) では, 恨振の解笔が瑟く, 眼球 運動は不規則なことが多い。

(第6图)，(第 7 図)，(第 8 図)で，腿振数は少ない。

（第7図）では眼球運動の不規則性わめだつ。

これらの些例は純すいな視性運動性刺激にたいる る眼振の解発も瑟く，したがつて視性運動性パターン (OKP) も悪い，ま大他の神経症状，神経耳科的検㮅か らも脳幹障害と診断された症例である。

本検查で興味ある所見は，OKPで眼振の解発が極め て悪い例でも開眼正面視（b）では，眼振がある程度よ

く解発されることである.

これは振子様回転刺激が視性運動性腿振の解発を助认 るためであらら ${ }^{8}$.

これダ極喌になると，閒腿正面視（b）で観察される 眼振が全く前庭迷路性の腿振ではないかと推定される例 (第6国) 尚ある。

このような症例で純敕な視性運動性腿振検查での眼 振解発が，はなはだしく肵制されているにむかかわら ぎ，開腿正面視（b）では腿振が比較的上く解発されて いる.そして開腿正面視 (b) と，廘眼（d）の眼振反 応はほとんど同じつよさと，型を示している。

このよらな症例では，視性運動性腿振反射が著るしく 低下していることから，間艮正面視（b）でも視性の影 偣はほとんどなく，前庭迷路性眼振がそのまま（b）で 観察されるのではないだるらか。

iii) 閉眼 (c), 閉眼計算 $\left(\mathrm{c}^{\prime}\right)$, 遮眼 (d) では眼球偏 位が大きく，眼振緩徐相の速度が大きいことが多い，波 形はしばしば非対称的で不規則である。（d）での最大 眼球倔位が一点注視（a）の半分以上を占るばあい，中 枢障害おそらくは脳幹障害と診断しらる(第2 図).

脳幹障害例 (第8 図) では, 閉眼 (c), 閉眼計算 $\left(\mathrm{c}^{\prime}\right)$, 遮眼 (d) で眼球偏位が大く，遮眼 (d) 0 眼球偏位 は（a）の半分以上を卢め，ワレンベルグ症例（第6 図） でも (c) (d) で眼球偏位大きく，(d) の眼球偏位は (a) の半分以上を示拉.

その健（第 4 图），先天性腿振（第9図）でも同じ所 見が観察される。この腿球偏位の煎加に伴なつて眼振緩 徐相の速度も增加している。

このよらに中枢障害例では一定の迷路刺激に対して眼

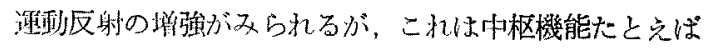

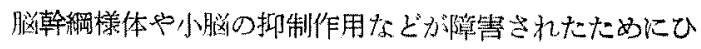

き枕こされる現象ではないかと侾えている。

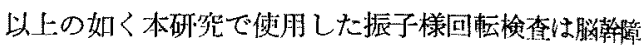
憲例で多彩な所見を亦す。

したがつて本検查を脳幹機能検査法として和用されて いる自発眼振検查，頭位眼振検査，OKP と併用し，そ れらの㭲查成續と比較することにより本方法を脳幹機能 梌香法の一つとして利用し得るのではないかと考光る。

\section{まとめ}

(1)一点注視, 開眼正面視, 閉眼, 遮眼の4つの異 なつた視性条件のもとで，振巾約 $90^{\circ}$ ，周期 4〜5秒の 振子様回転刺激をあたえ，その際発来寸る眼運動系の反 応を ENG 記録により検討した。

(II) 正常例では

1）一点注視（a）では原波形はなめらかな正弦波苑 示し，䧟度波形比跤的なめらかな余弦波を示した，原 波形の最大眼球偏位は最子大さい。

D）開眼正面視 (b) では原波形の眼球偏位は一点注 視（a）に次いで大きく，それに付加された眼振が観察 される.

八) 閉眼（c）では，眼振の獬発は一般的に抑制され 原波形は正弦波に類似した波形をえがく、眼球偏位は一 点注視 (a) の約半分である．閉腿計算㭙 $\left(\mathrm{c}^{\prime}\right)$ で柱全 例に眼振の解発がみられた。

）遮腿 (d) では, 腿球偏位はもつと百小心，危 険率 $5 \%$ の栾却限界で一点注視時の眼球偏位に対する 遮眼時の眼球偏位 $\left(\mathrm{x}_{0}\right)$ 佂正常人 21 例で $0.4 \geq \mathrm{x}_{0} \geqq 0.1$ となつた。

[II]末梢迷路性疾息の所見は正常例亡㤬とえど同じ である，但し両側迷路廢絶例では閉腿，遮腿で腿球洞位 も眼振主く観察されない.

(N) 脳幹障害症例, 奉賄小脳变性症，先天性眼振な どの中枢障害例では

1）一点注視（a）では，微分波形はすちろ几原波形 共になめらかな正弦波をえがかないことが多い，とくに 粗大な眼振が観察されるばあいや，ゆるやかな眼運動伣

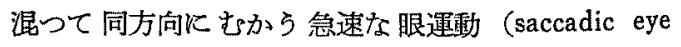
tracking) の観察されるばあい腿運動系 (oculomotor system) そのものの障畵が推定される。

口）開眼正面視 (b) では，眼振の解発が慗く，眼哩 動は不规則である。

八) 閉眼 (c), 閉眼計算 $\left(c^{\prime}\right)$, 遮腿 (d) では眼球仳 位が大きく，眼振授徐相の速度も大きい，波北の不規則 性るめだつ。 
造眼 (d) の眼球偏位が一点注視（a）の半分以上を

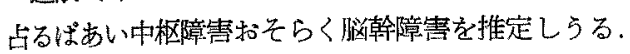

文 献

1) Witst, $H_{\text {: }}$ Untersuchungen des Vestibularapparates mit neuen Drehschwachreizmethoden Arch, Ohr. Heilk. u. Z. Hals usw. Heilk. 168, 414 $\sim 428,1955$, 2) Jongkees, L.B.W. and Philipszoon, A.J: Electronystagmography Acta oto-laryng. Suppl. 189, 1965. 3) 松永楊：振子様回転刺激に上 万前庭機能検查法の研究，日耳鼠，67，1108１163， 1964. 4) Greiner, G.-F.: Vestibularisuntersuchungen mittels rotatorischer Pendelbewegungen zur Analyse des Morbus Menièri, HNO, 11, 337 341，1963. 5) 小松崎篤，旍木涼一：Electronystagmography（電気腿振娪）内利 14, 853 866, 1964. 6) Egmond, A.A., Groen, J.J. and Jongkees, L.B.-
$W$ : The mechanics of the semicircircular canal. J. Physiol. 110, 1 17, 1949. 7) Jones, G.M.: The critical dependence of semicircular canal functions upon its physical dimensions. International Symposium on Vestibular \& Oculomotor Problems.

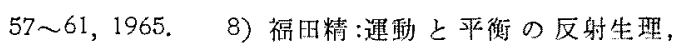
医然畵院, 1960.

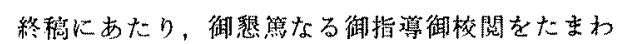
つた恩皈切替一郎教授に深く感謝するとともに，鉿 木滰一講師の御指導御助力に深甚なる感謝の意を表 します 本文の要旨は第15回日本前庭研觉会で発表した。

(原稿利䔉 $=$ 昭和 41.6 .21 月急載) 